\title{
Endovascular repair of traumatic external iliac vessel pseudoaneurysm and arteriovenous fistulae
}

\author{
Tratamento endovascular de pseudoaneurisma traumático e \\ fístulas arteriovenosas em vasos ilíacos externos
}

Juan Marín', Beatriz Retamales', Camila Onetto², Enrique Ceroni', Cristian Marín³

\begin{abstract}
A 17-year-old male patient presenting with an abdominal gunshot wound and severe hypovolemic shock was initially operated and presented several injuries to the small bowel and cecum associated with severe hemorrhage. The patient had to be operated twice due to hypothermia, acidosis, and coagulopathy. In the late postoperative period, murmur and fremitus were observed. Angiography revealed a pseudoaneurysm associated with arteriovenous fistulae at the left external iliac vessels. Lesions were repaired with a stent graft placed in the external iliac artery, with a satisfactory outcome. Control computed tomography performed 6 months later evidenced artery integrity with closure of the fistulae. Endovascular therapy should be the preferred method in this type of vascular trauma complications.
\end{abstract}

Keywords: iliac vessels; trauma; pseudoaneurysm; arteriovenous fistulae.

\begin{abstract}
Resumo
Um paciente do sexo masculino com 17 anos de idade apresentando-se com ferimento abdominal por arma de fogo e choque hipovolêmico grave foi inicialmente operado e apresentava várias lesões no intestino delgado e ceco associadas a hemorragia grave. O paciente teve que ser operado duas vezes devido a hipotermia, acidose e coagulopatia. No período pós-operatório tardio, foram observados sopro e frêmito. Angiografia revelou um pseudoaneurisma associado a fístulas arteriovenosas nos vasos ilíacos externos ao lado esquerdo. As lesões foram tratadas mediante a colocação de stent na artéria ilíaca externa, com desfecho satisfatório. Tomografia computadorizada de controle realizada após 6 meses evidenciou integridade da artéria, com o fechamento das fístulas. O tratamento endovascular deve ser o método de escolha nesse tipo de complicação vascular traumática.
\end{abstract}

Palavras-chave: vasos ilíacos; trauma; pseudoaneurisma; fístulas arteriovenosas.

\section{INTRODUCTION}

Traumatic iliac vessel injuries, especially those secondary to penetrating gunshot wounds, are associated with a high mortality rate and pose a tremendous challenge to trauma surgeons. Patients usually present at the emergency department in shock, due to massive blood loss. In addition, they frequently initiate a vicious circle of hypothermia, coagulopathy, and acidosis ${ }^{1}$. Late complications such as pseudoaneurysms and arteriovenous fistulae are not frequent and can be missed during the first assessments. These complications are difficult to repair using conventional vascular surgery techniques, ${ }^{2}$ but the endovascular techniques currently available offer less morbidity and mortality ${ }^{3}$. We report the case of a 17 -year-old male patient who presented with an abdominal gunshot wound. During hospitalization, external iliac vessel pseudoaneurysm and arteriovenous fistulae were diagnosed. These late complications were diagnosed through physical examination and an angiographic study (Figure 1). Injuries were repaired using the endovascular technique, with placement of a stent graft.

\section{CASE REPORT}

A 17-year-old male patient presenting with an abdominal gunshot wound was admitted to the emergency room showing signs of severe hypovolemic shock. He was immediately transferred to the operating room. Exploratory laparotomy revealed the presence of 4 liters of blood in the abdominal cavity, mesenteric and mesosigmoid

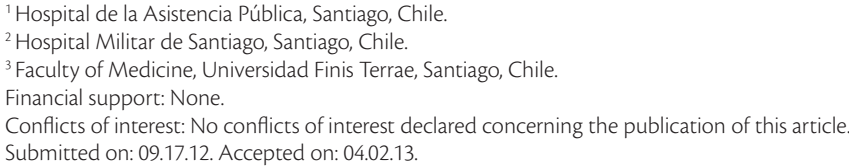




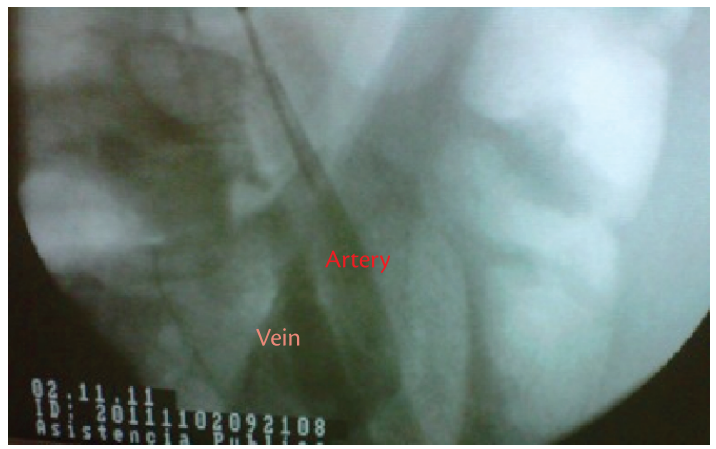

Figure 1. Traumatic pseudoaneurysm and arteriovenous fistulae affecting the left external iliac vessel.

bleeding injury, several small bowel perforations, and cecal perforation. No retroperitoneal hematoma was found.

Due to hemodynamic instability, with persistent hypotension associated with coagulopathy, hypothermia, and acidosis throughout the surgical procedure, a decision was made to resect the injured bowel only $(80 \mathrm{~cm})$, with sealing of the ends, careful hemostasia, packing, and laparostomy. The patient was taken to the intensive care unit for a better control and improvement of his status. On the second day, the patient returned to the operating room, was re-explored, and bowel anastomosis was made. A retroperitoneal, non-expanding hematoma was discovered but not explored. He required 10 units of red blood cells, 22 units of platelets, and 10 units of fresh frozen plasma in order to achieve complete stabilization.

The patient showed a satisfactory evolution, without any complications, until the 20th postoperative day, when murmur and fremitus were observed in the left iliac fossa. These were detected through physical examination and further investigated using angiography in the operating room (computed tomography [CT] was not available).

Angiography was performed under local anesthesia and revealed an external iliac vessel pseudoaneurysm associated with arteriovenous fistulae (Figure 1). A $6 \times 40 \mathrm{~mm}$ Fluency ${ }^{\circledR}$ stent graft was installed using a contralateral common femoral artery approach, a RIM-type angiographic catheter, and a Terumo 0.35 hydrophilic guide wire. The procedure allowed to successfully exclude both the arteriovenous fistulae and the pseudoaneurysm.

The patient was discharged 3 days after the endovascular procedure. Abdominal CT obtained 6 and 12 months after surgery evidenced integrity of the external iliac vessels (Figures 2 and 3).

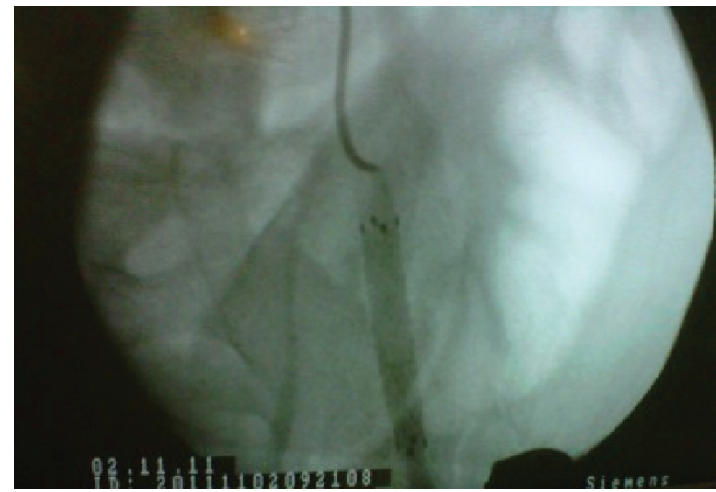

Figure 2. Control X-ray image showing immediate result after stent graft placement.

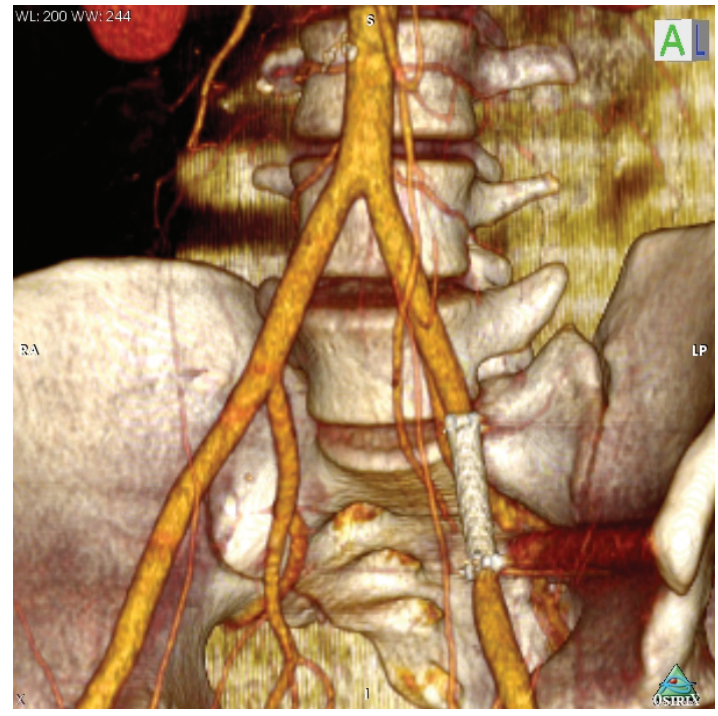

Figure 3. Control computed tomography image using intravenous contrast 12 months after surgery.

\section{DISCUSSION}

Gunshot injuries to the iliac vessels are marked by a high mortality rate due to severe bleeding and shock, in addition to a common association with lesions affecting the bowels and other organs. Diagnosis is usually easy, as these patients are admitted to the emergency room showing severe hemodynamic compromise due to internal bleeding.

Injuries to iliac vessels, such as pseudoaneurysms and arteriovenous fistulae, are infrequent and often missed $^{2}$ or diagnosed late. Radiological studies are appropriate for the diagnosis ${ }^{3}$. Surgical treatment is generally complex, as the artery needs to be replaced with a prosthetic material, and sometimes the contiguous venous conduit has to be ligated, increasing the risk for pulmonary embolism, deep vein thrombosis, and posthrombotic syndrome ${ }^{4}$. 
Notwithstanding, with the endovascular techniques currently available, these injuries can be repaired with less associated complications.

The rare reports found in the literature about the endovascular repair of this type of injury describe lesions affecting the primitive iliac vessels, mainly associated with lumbar disk surgeries ${ }^{5}$. The technique has shown important advantages compared to conventional surgery, especially a minimally invasive nature, local anesthesia, minimal blood loss, and faster rehabilitation.

After reviewing the literature and describing the advantages of the endovascular technique, and also after analyzing our own experience in this particular case, we have no doubts that endovascular therapy should be the treatment of choice in these specific type of traumatic injury. This recommendation is reinforced by the absence of studies published within the last 5 years describing external iliac vessel injuries associated with pseudoaneurysm and arteriovenous fistulae secondary to traumatic gunshot wounds, except for the few references describing compromise of the common iliac vessels due to lumbar disk surgery.

\section{REFERENCES}

1. Ascencio J, Petrone P, Roldán G, et al. Analysis of 185 Iliac Vessel Injuries Risk Factors and Predictors of Outcome. Arch Surg. 2003;138:1187-94.

2. Brewster D, Cambria R, Moncure A, et al. Aortocaval and iliac arteriovenous fistulas: Recognition and treatment. J Vasc Surg. 1991;13:253-65.

3. Antoniou G, Koutsias S, Karathanos Ch, Sfyroeras GS, Vretzakis G, Giannoukas AD. Endovascular Stentgraft repair of mayor abdominal arteriovenous fistula: A systematic review. J Endovasc Ther. 2009; 16:514-23.

4. Perry M. Complications of missed arterial injuries. J Vasc Surg.1993;17:399-407.

5. Hart J, Wallis F, Kenny B, O'Sullivan B, Burke PE, Grace PA. Endovascular exclusion of iliac artery to iliac vein fistula after lumbar disk surgery. Case Report . J Vasc Surg. 2003;37:1091-3. Correspondence
Juan Marín Peralta
Hospital de la Asistencia Pública
La Araucana, 728, La Reina
Santiago - Chile
E-mail: jmarin1953@gmail.com

Author information

JM, BR are Vascular surgeon, Hospital de la Asistencia Pública, Santiago, Chile.

$\mathrm{CO}$ is General surgeon, Hospital Militar de Santiago, Santiago, Chile EC is Vascular surgeon, Hospital de la Asistencia Pública, Santiago, Chile

CM is Medical student, Faculty of Medicine, teacher assistant at the Clinical Simulation Center of the Faculty of Medicine of Universidad Finis Terrae, Santiago, Chile.

Author contributions Conception and design: JM, EC, BR Analysis and interpretation: JM, CO Data collection: $\mathrm{CO}, \mathrm{JM}$ Writing the article: $\mathrm{CO}, \mathrm{CM}$ Critical revision of the article: JM Final approval of the article*: JM Statistical analysis: N/A Overall responsibility: JM Obtained funding: None

${ }^{*}$ All authors should have read and approved of the final version of the article submitted to J Vasc Bras. 
